\title{
STRUKTUR KOMUNITAS MAKROALGA DI PERAIRAN DESA LANGARA BAJO KONAWE KEPULAUAN
}

\section{Community Structure Of Macroalgae in Langara Bajo Waters Konawe Islands}

\author{
Nurlela $^{1}$, Wa Nurgayah ${ }^{2}$, dan Emiyarti ${ }^{3}$ \\ ${ }^{1}$ Jurusan Ilmu Kelautan, Fakultas Perikanan dan Ilmu Kelautan Universitas Halu Oleo \\ J1. HAE Mokodompit Kampus Baru Tridarma Anduonohu Kendari 93232, Telp/Fax: (0401) 3193782 \\ ${ }^{2}$ Surel: nurgayah_fish@yahoo.com
}

\begin{abstract}
Abstrak
Makroalga merupakan sumber daya hayati laut yang memiliki nilai ekonomis penting yang dimanfaatkan sebagai bahan makanan dan obat-obatan. Penelitian ini dilaksanakan di Perairan Desa Langara Bajo Konawe Kepulauan yang bertujuan untuk menggetahui Struktur Komunitas Makroalga, seperti indeks keanekaragaman, indeks keseragaman, indeks dominansi, dan pola sebaran makroalga. Penelitian ini dilaksanakan pada bulan April-Mei 2018, yang meliputi pengambilan data dan penggolahan data penelitian. Pengambilan data dilakukan dengan metode transek kuadrat. Pengambilan data di setiap stasiunnya dilakukan sebannyak 3 kali. Jenis makroalga yang diperoleh yaitu Halimeda opuntia, Neomeris vanbosseae, Valonia fastigiata, Dictyosphaeria cavernosa, Halimeda discoidea, Halimeda tuna, Halimeda macrobola, Ceulerpa serrulata, Chlorodesmis fastigiata, Turbinaria ornota, Dictyota bartayresiana, Padina australis, Sargassum polycystum, Amphiroa fragilissima, Glacilaria cotoni, Acanthopora spicifera, Laurencia tronai, dan Glacilaria salicornia. Indeks keanekaragaman jenis makroalga (H') berkisar antara 0,748-2,182, indek keseragaman (E) berkisar antara $0,477-0,878$, indeks dominansi (D) berkisar antara $0,144-0,581$, pola sebaran (Id) berkisaran antara 0,705-2,903 termasuk kategori merata dan mengelompok. Substrat pada lokasi penelitian bertekstur pecahan karang dan pasir.
\end{abstract}

Kata Kunci: Struktur Komunitas, Makroalga, Perairan Desa Langara Bajo.

\begin{abstract}
Macroalgae is a marine biological resource that has important economic value which is used as food and medicine. This research was conducted in the Langara Bajo Waters of Konawe Islands which aimed to determine the macroalgae community structures, such as diversity index, uniformity index, dominance index, and macroalgae distribution patterns. This research was conducted in April-May 2018, which included data collection and processing of research data. Data retrieval was done by the quadratic transect method. Data collection at each station was done three times. The types of macroalgae obtained were Halimeda opuntia, Neomeris vanbosseae, Valonia fastigiata, Dictyosphaeria cavernosa, Halimeda discoidea, Halimeda tuna, Halimeda macrobola, Ceulerpa serrulata, Chlorodesmis fastigiata, Turbinaria ornota, Dictyota bartayresiana, Padina australis, Sargassum polycystum, Amphiroa fragilissima, Glacilaria cotoni, Acanthopora spicifera, Laurencia tronai, and Glacilaria salicornia. The diversity index of macroalgae (H') ranged from $0.748-2.182$, the uniformity index (E) ranged from $0.477-0.878$, dominance index (D) ranged from $0.144-0.581$, and the distribution pattern (Id) ranged from $0.705-2.903$ was included evenly distributed categories and on groups. The substrate in the study location was shattered with rubble and sand.
\end{abstract}

Keywords: Community Sructure, Macroalgae, Waters of Langara Bajo

\section{Pendahuluan}

Makroalga mempunyai nilai ekonomis penting dan sudah banyak dimanfaatkan, antara lain sebagai bahan makanan, obat, dan material penting pada berbagai industri (Angka dan Suhartono, 2000). Makroalga dapat dimanfaatkan sebagai bahan obat dan farmasi karena mempunyai daya antiviral, antifouling, dan berpotensi sebagai anti kanker paru-paru, tumor dan AIDS (Smith, 2004).

Keberadaan makroalga sebagai organisme banyak sekali memberikan manfaat bagi kehidupan akuatik terutama bagi organisme herbivora perairan laut maupun sebagai penyedia karbonat di perairan laut. Diperkirakan bahwa produksi bersih rumput laut yang memasuki jaring makanan melalui pemangsaan (grazing) hanya $10 \%$, sedangkan sisanya sebesar $90 \%$ masuk melalui rantai bentuk detritus atau bahan organik terlarut (Nyabakken, 1992).

Berdasarkan hasil penelitian Wulham (2006) di perairan Desa Sorue menemukan 7 spesies makroalga yaitu 2 spesies 
Rhodophyta, 3 jenis jenis Phaeophyta dan 2 jenis Chlorophyta. Penelitian Fauzan di perairan Desa Waduri (2010) menemukan 18 spesies makroalga yaitu 9 jenis Chlorophyta, 3 jenis Rhodophyta dan 5 jenis Phaeophyta. Irwandi dkk., (2017) menyatakan bahwa komposisi jenis makroalga yang ada di perairan Desa Tanjung Tiram terdiri dari 13 jenis makroalga diantaranya 4 jenis Chlorophyta, 7 jenis Phaeophyta, dan 2 jenis Rhodophyta.

Perairan Desa Langara Bajo Kabupaten Konawe Kepulauan merupakan daerah yang memiliki potensi sumberdaya hayati dan makroalga yang cukup padat dimana makroalga ini banyak di temukan di daerah yang padang lamun dan daerah terumbu karang yang masih mendapatkan sinar matahari untuk melakukan proses fotosintesis. Hasil penelitian Papalia dan Arfah (2013) menyatakan bahwa jenis-jenis rumput laut yang dijumpai terdiri dari kelompok rumput laut merah (Rhodophyta), hijau (chlorophyta), dan coklat (Phaeophyta). Kehadiran jenis rumput laut yang dijumpai pada paparan terumbu karang dengan kedalaman perairan yang dangkal berkisar antara 1-5 meter.

Keberadaan makroalga pada Perairan Desa Langara Bajo ini sangat penting dimana dapat melindungi dan sebagai tempat mencari makan bagi organisme yang membutukannya. Hasil survei menunjukan bahwa daerah ini makroalganya belum teridentifikasi. Oleh karena itu maka perlunya dilakukan penelitian mengenai Struktur Komuninas makroalga di Perairan Desa Langara Bajo Konawe Kepulauan.

\section{Bahan dan Metode}

Penelitian ini dilaksanakan dari bulan April-Mei 2018, yang meliputi pengambilan data dan pengolahan data penelitian. Lokasi pengambilan sampel dan data penelitian di Perairan Desa Langara Bajo, Kabupaten Konawe Kepulauan, Provinsi Sulawesi Tenggara. Peta lokasi penelitian di Perairan Desa Langara Bajo, Konawe Kepulawan disajikan pada Gambar 1. Parameter substrat selanjutnya dianalisis di Laboratorium Pengujian Bahan dan Konstruksi Program Studi S1 Teknik Sipil Fakultas Teknik.

Penentuan stasiun tersebut dilakukan melalui observasi lapangan dilakukan dengan tujuan untuk mengetahui gambaran umum lokasi penelitian yang ada di Perairan Desa Langara Bajo Konawe Kepulauan.

Setelah dilakukan observasi selanjutnya penentuan lokasi penelitian, dimana penentuan titik stasiun ini ditentukan sebanyak tiga stasiun berdasarkan keberadaan makroalga. Stasiun I: Terletak di Perairan Desa Langara Bajo, dengan posisi geografis 03058'54,40''LS dan 12300'28,19'BT. Stasiun ini berada di daerah Terumbu Karang dan Pecahan Karang dengan kondisi substrat Pecahan Karang. Stasiun II: Terletak di Perairan Desa Langara Bajo, dengan posisi geografis 03059'46,5' LS dan 12300'1,69' 'BT. Stasiun ini berada di daerah Lamun dengan kondisi substrat berpasir. Stasiun III: Terletak di Perairan Desa Langara Bajo, dengan posisi geografis 0400'44,28' LS dan $122059^{\prime} 43,8^{\prime}$ 'BT. Stasiun ini berada di daerah Lamun yang dekat dengan pemukiman dengan kondisi substrat yang berpasir.

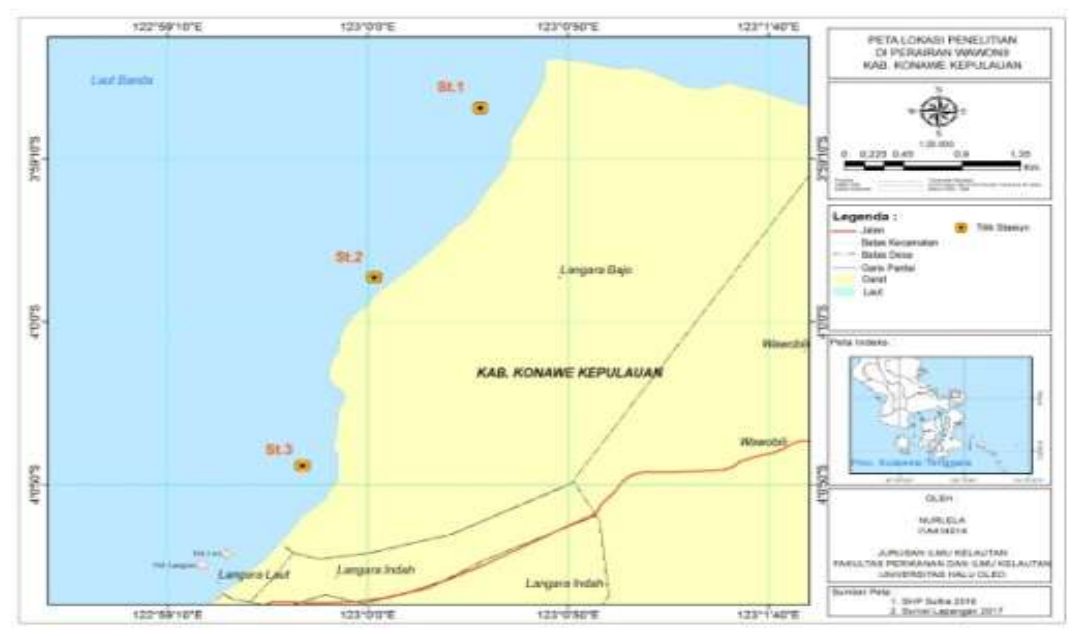

Gambar 1: Peta Lokasi Penelitian 
Pengambilan sampel makroalga diperoleh dengan menggunakan metode transek garis (Fachrul, 2007). Transek garis yang dibentangkan tegak lurus dari garis pantai ke arah laut sepanjang $100 \mathrm{~m}$. Masingmasing garis transek diletakan transek kuadrat $(1 \mathrm{~m} \times 1 \mathrm{~m})$. Pengambilan data di setiap stasiunnya dilakukan sebanyak 3 kali penggulangan di stasiun tersebut.

Sampel makroalga yang terdapat di dalam transek dihitung jumlah per jenis (setiap individu atau tegakan) kemudian mengambil untuk didokumentasikan dengan menggunakan kamera digital. Kemudian makroalga yang tidak dapat diidentifikasi dimasukkan kedalam plastik sampel dan diidentifikasi sesuai dengan panduan Herandarudewi (2015), Setyobudiandi dkk., (2009) dan (Jha et all., 2009). Pengambilan sampel makroalga dilakukan pada saat air surut dan dibantu dengan alat snorkeling.

Paremeter fisika yang diukur secara langsung di lapangan yaitu suhu, kedalaman, kecerahan, dan kecepatan arus sedangkan parameter kimia yang diukur secara langsung di lapangan yaitu salinitas dan $\mathrm{pH}$. Penggukuran kualitas air ini dilakukan sebanyak 3 kali penggulangan untuk setiap stasiunnya.

Keanekaragaman jenis makroalga dihitung dengan menggunakan persamaan Odum, (1996) sebagai berikut:

$$
H^{\prime}=-\sum_{i=1}^{i} \text { Pi LnP }
$$

Keterangan :

H'= Indeks keanekaragaman Jenis

$\mathrm{Pi}=$ Kelimpahan relatif ke- $\mathrm{i}$

$\mathrm{ni}=\mathrm{Jumlah}$ individu jenis

$\mathrm{N}=$ Jumlah individu keseluruhan

Keseragaman dapat dikatakan sebagai keseimbangan, yaitu komposisi individu tiap jenis yang terdapat dalam suatu komunitas. Untuk menghitung keseragaman jenis dapat dihitung dengan menggunakan rumus Odum, (1996) berikut:

$\mathrm{E}=\frac{\mathrm{H}^{\prime}}{\mathrm{H}_{\max }}$

Keterangan:

$\mathrm{E}=$ Indeks keseragaman

$\mathrm{H}^{\prime}$ = Indeks keanekaragaman

$\mathrm{H}_{\max }=$ Keanekaragaman spesies maksimum $(\ln S)$

Indeks dominansi dihitung dengan menggunakan rumus Odum, (1996) sebagai berikut:

$\mathrm{D}=\sum(\mathrm{ni} / \mathrm{N})^{2}$

Keterangan:

$\mathrm{D}=$ Indeks dominansi

$\mathrm{ni}=$ Jumlah individu spesies ke- $\mathrm{i}$

$\mathrm{N}=$ Jumlah total spesies

Pengamatan sebaran jenis makroalga dilakukan berdasarkan persamaan pola sebaran Morisita (Id) kemudian makroalga diidentifikasi dan dibuat hasil identifikasi jenis makroalga tersebut pada setiap stasiun pengamatan dalam bentuk tabel. Berikut persamaan pola sebaran Morisita (Id) menurut Brower dan Ende (1990)

$\mathrm{Id}=n \frac{\sum x^{2}-N}{N(N-1)}$

Keterangan:

$\mathrm{Id}=$ Indeks dispersi morisita

$\mathrm{n}=$ Jumlah plot pengambilan contoh

$\mathrm{N}=$ Jumlah individu total dalam plot

$\mathrm{X}^{2}=$ Jumlah individu pada setiap plot ke-i

Analisis tipe substrat dilakukan dengan metode saringan bertingkat menggunakan skala wenworth, untuk mengetahui tipe substrat pada stasiun penelitian. Klasifikasi butiran tanah disajikan pada Tabel 1 .

Tabel 1. Skala Wenworth Klasifikasi Butiran Tanah (Hutabarat dan Evans, 1985).

\begin{tabular}{clc}
\hline No. & Nama Butiran & Ukuran \\
\hline 1. & Boulders (kerikil besar) & $>256$ \\
2. & Gravel (kerikil kecil) & $2-256$ \\
3. & Very coarse sand (pasir sangat kasar) & $1-2$ \\
4. & Coarse sand (pasir kasar) & $0,5-1$ \\
5. & Medium sand (pasir sedang) & $0,25-1$ \\
6. & Fine sand (pasir halus) & $0,125-0,25$ \\
7. & Very fine sand (pasir sangat halus) & $0,0625-0,0625$ \\
8. & Silt (debu/lanau) & $0,002-0,0625$ \\
9. & Clay (lempung) & $0,0005-0,002$ \\
10. & Dissolved material (material terlarut) & $<0,0005$ \\
\hline
\end{tabular}




\section{Hasil dan Pembahasan}

Jenis makroalga yang ditemukan di lokasi penelitian berjumlah 18 jenis yaitu 9 jenis dari devisi Chlorophyta, 4 jenis dari devisi Phaeophyta, dan 5 jenis dari devisi Rhodophyta. Jenis yang paling banyak ditemukan yaitu jenis Pedina australis dan jenis yang paling sedikit ditemukan yaitu Chlorodesmis fastigiata dan Dictyota bartayresiana. Hal tersebut dikarenakan jenis Padina australis memiliki toleransi yang baik terhadap faktor lingkungan seperti suhu, kedalaman, kecerahan, keceptan arus, salinitas $\mathrm{pH}$ yang ada di Perairan Desa Langara Bajo.

Jenis makroalga yang ditemukan pada stasiun I lebih banyak dibandingkan dengan stasiun II dan stasiun III. Stasiun I terletak di daerah rataan terumbu karang, dan karang mati dengan tekstur substrat pecahan Karang sehingga makroalga yang terdapat di daerah tersebut memiliki keanekaragaman jenis makroalga yang melimpah. Makroalga yang ditemukan pada stasiun ini yaitu makroalga jenis Amphiroa fragilissima, Halimeda opuntia, Glacilaria cotoni, Neomeris vanbosseae, Acanthopora spicifera, Laurencia tronai, Valonia fastigiata, Dictyosphaeria cavernosa, Chlorodesmis fastigiata, Halimeda tuna, dan Turbinaria ornota. Hal ini dipertegas oleh Yudasmara, (2011) yang menyatakan bahwa, karang dapat menjadi media hidup alga karena sebagian besar makroalga hidup dengan cara menempel, terutaman pada substrat yang keras seperti pecahan karang (rubble), karang mati serta benda-benda keras yang terendam di dasar laut. Selanjutnya Atmadja (1999), menyatakan bahwa tempat-tempat yang memiliki substrat pacahan karang mati, karang masif dan pasir yang lebih stabil ditemukan jumlah jenis makroalga yang lebih banyak dibandingkan dengan tempat-tempat yang hanya bersubstrat pasir dan lumpur.

Stasiun II terdapat 4 jenis makroalga Halimeda macrobola, Ceulerpa serrulata, Halimeda opuntia, dan Dictyota bartayresiana. Stasiun III terdapat 5 jenis makroalga Padina australis, Sargassum polycystum, Glracilaria salicornia dan Dictyota bartayresiana. Hal ini di pertegas oleh Ain $d k k .$, (2014) bahwa rumput laut yang paling banyak ditemukan pada substrat pasir adalah jenis Halimeda macrobola, sedangkan yang paling jarang ditemukan pada substrat pasir adalah jenis Sargasum pululiferum. Hasil penelitian Ariani (2016), yang menyatakan bahwa makroalga yang hidup di daerah yang bersubstrat pasir yaitu makroalga dari kelas Chlorophyta dengan presentase komposisi jenis sebesar $95 \%$ dari jenis Halimeda yaitu Halimeda macrobola, Halimeda boorneensis dan Halimeda discoidea. Kelas Rhodophyta hanya terdapat Glacilaria cotoni, Glracilaria salicornia, dan Glracilaria verrucosa dan dari kelas Phaeophyta hanya terdapat Padina australis. Kelas Chlorophyta merupakan alga yang dominan disebabkan substrat hidupnya pasir. Tingginya komposisi makroalga hijau karena alga ini umumnya lebih cenderung tumbuh dengan vegetasi tumbuhan lamun dari jenis Enhalus acroides dan Thallasia hemprichii. Hasil penelitian mkroalga yang ditemukan pada lokasih penelitian disajikan pada Tabel 3 disamping. Hasil penelitian yang telah dilakukan oleh Ali (2010) menemukan 16 jenis makroalga, 5 jenis dari devisi Chlorophyta, 5 jenis dari devisi Rhodophyta dan 6 jenis dari devisi Phaeophyta. Jenis makroalga pada perairan tersebut lebih banyak ditemukan dari devisi Phaeophyta karna disebabkan oleh tekstur substrat yang berpasir dan substrat pecahan karang mati. Pada penelitian yang dilakukan oleh Ariani (2016) diperoleh 13 jenis makroalga, 5 jenis dari devisi Chlorophyta, 3 jenis dari devisi Rhodophyta dan 5 jenis dari devisi Phaeophyta. Makroalga pada daerah ini lebih dominan pada devisi Chlorophyta karna disebabkan oleh substrat pasir dan pecahan karang.

Penelitian yang dilakukan oleh Rosdiana (2017) menemukan 10 jenis makroalga, 3 jenis dari devisi Chlorophyta, 2 jenis dari devisi Rhodophyta, dan 5 jenis dari devisi Phaeophyta. Makroalga yang ditemkan pada perairan tersebut lebih banyak ditemukan makroalga dari devisi Phaeophyta hal ini karna disebabkan oleh tekstur substrat yang pasir berlempung dan pecahan karang. Sedangkan penelitian yang dilakukan oleh Farito $d k k$., (2018) menemukan 5 jenis makroalga, 3 jenis dari devisi Chlorophyta, 1 jenis dari devisi Phaeophyta dan 1 jenis dari devisi Rhodophyta. Makroalga yang ditemukan di Perairan ini lebih dominan pada jenis makroalga dari devisi Chlorophyta karna disebabkan oleh jenis substrat terumbu karang buatan dari sampah plastik. 
Tabel 2. Jenis dan Jumlah Makroalga pada Perairan Desa Langara Bajo.

\begin{tabular}{|c|c|c|c|c|}
\hline \multirow[b]{2}{*}{ No. } & \multirow{2}{*}{ Jenis Makroalga } & \multicolumn{3}{|c|}{ Jumlah Makroalga } \\
\hline & & Stasiun I & Stasiun II & Stasiun III \\
\hline & Chlorophyta (alga hijau) & & & \\
\hline 1. & Halimeda opuntia & 80 & 232 & 110 \\
\hline 2. & Neomeris vanbosseae & 19 & - & - \\
\hline 3. & Valonia fastigiata & 22 & - & - \\
\hline 4. & Dictyosphaeria cavernosa & 10 & - & - \\
\hline 5. & Halimeda discoidea & 16 & - & - \\
\hline 6. & Halimeda tuna & 16 & - & - \\
\hline 7. & Halimeda macrobola & - & 70 & - \\
\hline 8. & Ceulerpa serrulata & - & 9 & - \\
\hline \multirow[t]{2}{*}{9.} & Chlorodesmis fastigiata & 1 & - & - \\
\hline & Phaeophyta (alga coklat) & & & \\
\hline 10. & Turbinaria ornota & 9 & - & - \\
\hline 11. & Dictyota bartayresiana & - & 7 & 6 \\
\hline 12. & Padina australis & - & - & 382 \\
\hline \multirow[t]{2}{*}{13.} & Sargassum polycystum & - & - & 9 \\
\hline & Rhodophyta (alga merah) & & & - \\
\hline 14. & Amphiroa fragilissima & 45 & - & - \\
\hline 15. & Glacilaria cotoni & 17 & - & - \\
\hline 16. & Acanthopora spicifera & 27 & - & - \\
\hline 17. & Laurencia tronai & 18 & - & - \\
\hline 18. & Glacilaria salicornia & - & - & 13 \\
\hline & $\begin{array}{l}\text { Jumlah } \\
\end{array}$ & 280 & 318 & 520 \\
\hline
\end{tabular}

Tabel 3. Hasil Perbandingan Penelitian Lain di Sulawesi Tenggara

\begin{tabular}{|c|c|c|c|c|c|}
\hline \multirow{2}{*}{ No. } & \multicolumn{3}{|c|}{ Devisi Makroalga } & \multirow{2}{*}{ Lokasih } & \multirow{2}{*}{ Peneliti } \\
\hline & Chlorophyta & Rhodophyta & Phaeophyta & & \\
\hline 1. & 5 Jenis & 5 Jenis & 6 Jenis & $\begin{array}{l}\text { Perairan Lakeba, } \\
\text { Bau-bau }\end{array}$ & $\begin{array}{l}\text { Fadillah Ali } \\
\text { (2010) }\end{array}$ \\
\hline 2. & 5 Jenis & 3 Jenis & 5 Jenis & $\begin{array}{l}\text { Desa Lalowaru, } \\
\text { Moramo Utara }\end{array}$ & Ariani (2016) \\
\hline 3. & 3 Jenis & 2 Jenis & 5 Jenis & $\begin{array}{l}\text { Perairan Waworaha } \\
\text { Kecamatan Soropia }\end{array}$ & Rosdiana (2017) \\
\hline 4. & 3 Jenis & 1 Jenis & 1 Jenis & $\begin{array}{l}\text { Perairan Tanjung } \\
\text { Tiram }\end{array}$ & $\begin{array}{l}\text { Farito } d k k ., \\
(2018)\end{array}$ \\
\hline 5. & 9 Jenis & 5 Jenis & 4 Jenis & Penelitian ini & \\
\hline
\end{tabular}

Tabel 4. Indeks Keanekaragaman Jenis (H'), Indeks Keseragaman (E), dan Indeks Dominansi (D) Makroalga pada Lokasi Penelitian

\begin{tabular}{ccccccc}
\hline Stasiun & H' & Kategori & E & Kategori & D & Kategori \\
\hline I & 2,182 & Sedang & 0,878 & Besar & 0,144 & Rendah \\
II & 0,748 & Rendah & 0,539 & Sedang & 0,581 & Sedang \\
III & 0,769 & Rendah & 0,477 & Sedang & 0,585 & Sedang \\
\hline
\end{tabular}


Indeks keanekaragaman merupakan salah satu struktur komunitas yang digunakan untuk menentukan keanekaragaman jenis organisme di suatu perairan. Indeks keanekaragaman jenis makroalga stasiun I yaitu 2,182, stasiun II yaitu 0,748 , dan stasiun III yaitu 0,769 (Tabel 4). Indeks keanekaragaman di Perairan Desa Langara Bajo menunjukan keanekaragaman yang sedang $1<\mathrm{H}^{\prime} \leq 3$ dan rendah $\mathrm{H}^{\prime}<1$ (Odum, 1996).

Stasiun I memiliki indeks keanekaragaman jenis makroalga dengan kategori sedang dibandingkan dengan stasiun II dan stasiun III dengan kategori rendah. Dimana stasiun I terdapat 12 jenis makroalga dengan jumlah total 280 individu, sedangkan pada stasiun II terdapat 4 jenis makroalga dengan jumlah total 318 individu dan pada stasiun III terdapat 5 jenis makroalga dengan jumlah total individu 520 individu. Hal ini disebabkan karena adanya perbedaan faktor lingkungan seperti substrat yang ditempati, dimana stasiun I kondisi substratnya pecahan karang sengangkan stasiun II dan stasiun III dengan kondisi substrat yang berpasir.

Romimohtarto dan Juwana (2005) yang menyatakan bahwa keanekaragaman jenis makroalga ditentukan pula oleh keanekaragaman habitat (substrat), di tempat yang memiliki substrat pecahan karang batu mati, karang masif dan pasir yang lebih stabil mempunyai keanekaragaman alga yang lebih tinggi dibandingkan dengan tempat yang hanya bersubsrat pasir dan lumpur. Selanjutnya Insafitri (2010) menyatakan bahwa perbedaan keragaman jenis makroalga bentik antara lokasi pengamatan tidak lepas dari jenis substrat dan gerakan air masingmasing lokasi certa alga bentik meletakan dirinya pada substrat.

Indeks keseragaman merupakan suatu indeks dari struktur komunitas yang digunakan untuk menentukan keseimbangan komposisi suatu individu. Indeks keseragaman makroalga pada stasiun I yaitu 0,878 , stasiun II yaitu 0,539 , dan stasiun III yaitu 0,477 (Tabel 4). Nilai indeks keseragaman di Perairan Desa Langara Bajo menunjukan nilai keseragaman yang berbeda-beda, dimana stasiun I memiliki indeks keseragaman yang besar dengan nilai E>0,6, stasiun II dan stasiun III memiliki nilai keseragaman yang sedang dengan nilai $0,<\mathrm{E}<0,6$.

Makroalga di Perairan Desa Langara Bajo memiliki nilai indeks keseragaman tiap stasiun berbeda-beda. Hal ini dikarenakan oleh faktor lingkungan seperti kecepatan arus. Kecepatan arus yang di peroleh yaitu $0,11 \mathrm{~m} / \mathrm{s}$ stasiun I, $0.07 \mathrm{~m} / \mathrm{s}$ stasiun II, 0.06 $\mathrm{m} / \mathrm{s}$ stasiun II. Nilai kecepatan arus yang pada stasiun II dan stasiun III dikatakan sangat rendah dan kurang baik untuk pertumbuhan makroalga dibandingkan dengan stasiun I. Hal ini sesuai dengan pernyataan Widyartini $d k k$., (2011) yang mengatakan bahwa kecepatan arus yang terendah menyebabkan thallus mudah di tempeli kotoran sehingga proses fotosintesis akan terhambat dan mengakibatkan pertumbuhan makroalga menjadi lambat. Nilai kecepatan arus yang baik untuk pertumbuhan makroalga $0,10-0,50 \mathrm{~m} / \mathrm{s}$ (Widyastuti, 2008).

Dimana hasil pengukuran kedalaman di Perairan Desa Langara Bajo berkisar antara 1,5-2 $\mathrm{m}$ dan 3,7 $\mathrm{m}$ dan masih dijangkau oleh penetrasi cahaya matahari sedangkan hasil pengukuran kecerahan pada daerah stasiun penelitian yaitu berkisar 100 $\%$. Hal ini dipertegas oleh (Ningsih, 2006) yang menyatakan bahwa kisaran rata-rata kecerahan yang baik untuk pertumbuhan makroalga yaitu $80-95 \%$. Selanjutnya Irwandi dkk., (2017) menyatakan bahwa kecerahan perairan menunjukan kemampuan cahaya untuk menembus lapisan air pada kedalaman tertentu, dimana kecerahan sangat penting karena erat kaitannya dengan proses fotosintesis.

Faktor lingkungan lain yang mendukung keberadaan makroalga di perairan ini seperti suhu, salinitas dan $\mathrm{pH}$. Dimana nilai suhu diperoleh $27-28^{\circ} \mathrm{C}$, salinitas yaitu $30 \mathrm{ppt}$, dan $\mathrm{pH}$ perairan pada ketiga stasiun tersebut diperoleh sebesar 7 . Hal ini di pertegas oleh Papalia dan Arafah (2013) dalam penelitiannya menyatakan bahwa parameter kualitas air yang tercatat selama penelitian masih berada pada kisaran yang layak mendukung pertumbuhan makroalga, dimana suhu berkisar antara $27,4-29,5^{\circ} \mathrm{C}$ dengan $\mathrm{pH}$ berkisar antara 7,0-8,5. Menurut Arafah dan Patty (2014) bahwa nilai salinitas yang baik untuk pertumbuhan makroalga berkisar antara 28-34 ppt. 
Tabel 5. Pola Sebaran Jenis Makroalga (Id) pada Lokasi Penelitian

\begin{tabular}{ccc}
\hline Stasiun & Pola Sebaran (Id) & Kategori \\
\hline I & 0,705 & Merata \\
II & 2,903 & Mengelompok \\
III & 2,923 & Mengelompok \\
\hline
\end{tabular}

Nilai indeks dominansi makroalga pada stasiun I yaitu 0,144 , stasiun II yaitu 0,581 , stasiun III yaitu 0,585 (Tabel 4). Nilai dominansi pada stasiun I dikategorikan rendah sedangkan stasiun II dan stasiun III di kategorikan sedang. Berdasarkan kisaran indeks dominansi $0<\mathrm{D}<0,50$ dan $0,50<\mathrm{D}<0,75 \quad$ (Odum, 1996). Makroalga yang mendominasi pada Perairan Desa Langara Bajo ini adalah makroalga devisi Chlorophyta dari genus Halimeda. Jenis alga ini sering ditemukan pada ketiga stasiun, hal ini menunjukan bahwa makroalga dari devisi Chlorophyta bisa hidup pada jenis substrat pecahan karang dan substrat berpasir. Hal ini dipertegas oleh Sukiman dkk., (2014) menyatakan bahwa Halimeda memiliki kemampuan untuk tumbuh dengan cara memancap dan menempel pada substrat berpasir pada ekosistem lamun dan terumbu karang maupun karang batu mati.

Rasjid, (2004) menyatakan bahwa adanya jenis yang mendominasi dapat dipengaruhi oleh persaingan antara makroalga yang ada. Persaingan antara makroalga maksudnya berkaitan dengan

Pola sebaran makroalga yang merata dan mengelompok disebabkan oleh faktor lingkungan dan faktor biologis makroalga. Dimana makroalga menggunakan holdfast sebagai alat untuk melekat pada substrat. Menurut Rosdiana (2017), pola sebaran makroalga disebabkan oleh faktor ekologi perairan yang dapat mengontrol keberadaan makroalga dan karasteristik biologis makroalga. Kehadiran spesies di suatu wilayah ditentukan oleh faktor karakteristik lingkungan dan karakteristik makroalga itu sendiri. Kesesuaian antara kedua faktor tersebut akan menentukan pertumbuhan makroalga termasuk kemampuan menempel pada tahap awal pertumbuhannya. Hal inilah yang menimbulkan perbedaan dalam kekayaan spesies dan sebaran makroalga pada suatu tempat dengan tempat yang lain (Kadi, 2005).

Pola sebaran makroalga yang merata disebabkan oleh faktor lingkungan yaitu kedalaman perairan dalam hal ini berkaitan mineral yang diperlukan, jika mineral yang dibutuhkan mendukung maka jenis tersebut akan lebih dominan dan lebih banyak ditemukan Indeks dominansi menunjukkan adanya satu atau lebih spesies yang mempunyai peranan yang jauh lebih besar terhadap komunitas dan lingkungan.

Nilai indeks dominansi yang tinggi atau rendah dipengaruhi juga rendah dan tingginya nilai keanekaragaman jenis makroalga. Hal ini sesuai dengan pernyataan Ferawati et al., (2014) bahwa suatu komunitas apabila terdapat organisme dengan tingkat dominansi yang rendah maka keanekaragamannya menjadi tinggi.

Pola sebaran jenis makroalga

dibedakan atas tiga kriteria yaitu pola penyebaran secara acak, merata dan mengelompok. Berdasarkan hasil penelitian yang telah dilakukan stasiun I menunjukan pola sebaran yang merata dengan nilai 0,705 sedangkan stasiun II dengan nilai 2,903 dan stasiun III dengan nilai 2,923 yang menunjukan pola sebaran yang mengelompok (Tabel 5) disamping.

dengan proses masuknya cahaya matahari hingga dasar perairan. Kedalaman perairan pada stasiun I yaitu 3,7 m dimana kondisi perairan ini masih dapat ditembus oleh cahaya matahari yang merupakan salah satu faktor yang membantu makroalga fotosintesis di perairan. Hal ini sesuai pertanyaan Huzaifah (2009), menyatakan bahwa penyebaran dan pertumbuhan alga di perairan dipengaruhi oleh intensitas cahaya matahari dan kedalaman dasar laut.

Pola sebaran makroalga yang mengelompok disebabkan oleh jenis substrat tempat tumbuhnya makroalga. Pada stasiun penelitian II dan III, makroalga ditemukan menyebar secara mengelompok karna disebabkan oleh jenis substrat yang sama yaitu pasir. Hal ini sesuai dengan pernyataaan Fauzan (2010), bahwa organisme yang mempunyai pola penyebaran mengelompok menyenangi kondisi substrat yang sama. 


\section{Simpulan}

Berdasarkan hasil penelitian yang telah dilakukan di Perairan Desa Langara Bajo dapat disimpulkan yaitu sebagai berikut:

1. Keanekaragaman jenis makroalga berada pada kategori sedang dan rendah, keseragaman makroalga berada pada kategori tinggi dan sedang, dan dominansi makroalga berada pada kategori tinggi dan sedang.

2. Pola sebaran makroalga di perairan Desa Langara Bajo yaitu merata dan mengelompok.

3. Parameter lingkungan yang mendukung pertumbuhan makroalga yang ada di Perairan Desa Langara Bajo yaitu parameter suhu, salinitas dan $\mathrm{pH}$.

\section{Daftar Pustaka}

Ali, F. 2010. Studi Ekologi Makroalga (sea weed) di Perairan Lakeba Kota BauBau. Universitas Halu Oleo. Kendari.

Ain, Nur. Ruswahyuni, Widyorini, N. 2014. Hubungan Kerapatan Rumput Laut dengan Substrat Dasar Berbeda di Perairan Pantai Bandengan Jepara. Diponegoro Journal of Maquares.(3)1:99-107

Angka, S.L dan Suhartono, T. S. 2000. Bioteknologi Hasil Laut. Bogor: Pusat Kajian Sumber Daya Pesisir dan Lautan. Institut Pertanian Bogor.

Arfah, H dan Patty, S. I. 2014. Keanekaragaman dan Biomassa Makroalga di Perairan Teluk Kotania, Seram Barat. LIPI. Jakarta.

Ariani, 2016. Komposisi dan Distribusi Makroalga Berdasarkan Tipe Substrat di Perairan Desa Lalowaru Kecamatan Moramo Utara. Universitas Halu Oleo. Kendari.

Atmadja, W.S. 1999. Sebaran dan Beberapa Aspek Vegetasi Rumput Laut (Makroalga) di Perairan Terumbu Karang Indonesia. Puslitbang Oceamologi-LIPI. Jakarta

Brower, J. E., J. H. Zar and C. von Ende. 1990. Ekologi Umum. Metode Lapangan dan Laboratorium. Wm. C. Brown Company Publisher, Dubuque, Iowa.

Fachrul, M, F., 2007. Metode Sampling Bioekologi. Penerbit Bumi Aksara. Jakarta
Farito, Kasim, M, Nur, I. A. 2018. Studi Kepadatan Dan Keanekaragaman Makroalga pada Terumbu Karang Buatan dari Sampa Plastik di Perairan Desa Tanjung Tiram Kecamatan Moramo Utara Kabupaten Konawe Selatan. Jurnal Menejemen Sumber Daya Perairan. 3(2): 93-103

Fauzan, T.H. 2010. Studi Keanekaragaman dan Pola Penyebaran Makroalga di Perairan Pantai Desa Waduri, Kecamatan Kaledupa, KabupatenWakatobi, Sulawesi Tenggara. Universitas Halu Oleo. Kendari.

Ferawati, E., Widyartini, D. S. dan Insan, I. 2014. Studi Komunitas Rumput Laut pada berbagai Substrat di Perairan Pantai Permisan Kabupaten Cilacap. Universitas Jenderal Soedirman. Purwokerto.

Herandarudewi, S. M. C. 2015. PanduanWisata Edukasi Kelautan (Makroalga). LIPI. Jakarta.

Hutabarat, S. dan S.M. Evans.1985. Pengantar Oseanografi, Universitas Indonesia. Press. Jakarta.

Huzaifah, H. 2009. Ganggang (Alga). Universitas Muhammadiyah Indonesia.

Insafitri, 2010. Keanekaragaman, Keseragaman, dan Dominansi Bivalvi di Area Buangan Lumpur Lapindo Muara Sungai Porong. Jurnal Kelautan, 3(1) : 54-59.

Irwandi, Salwiyah, dan Nurgayah, W. 2017. Stuktur Komunitas Makroalga pada Substrat yang berbeda di Perairan Desa Tanjung Tiram Kecamatan Moramo Utara Kabupaten Konawe Selatan Provinsi Sulawesi Tenggara. Jurnal Menejemen Perairan. 2(3). 215-224 hal

Jha, B., Raddy, C. K. R., Thakur, M. C., dan Rao, M. U. 2009. Seaweeds of India the Diversity and Distributions of seaweeds of the Gujarat Coarst.

Kadi, A. 2005. Makroalgae di Perairan Kepulauan Bangka, Belitungdan Karimata. Jour. Mar. Sci. Univ. Diponegoro.

Ningsi, D. 2006. Struktur Komunitas Alga Laut Makrobentik di Pantai TNB Jamber 
Nybakken, J. W., 1992. Biologi Laut Suatu Pendekatan Ekologis. PT. Gramedia. Jakarta.

Odum, E. P. 1996. Fundamental of ecology. Gajamada University Press. Yogyakarta

Papalia S dan Arfah H. 2013. Produktivitas Biomasa Makroalga di Perairan Pulau Ambalau, Kabupaten Buru Selatan. Jurnal Ilmu dan Teknologi Kelautan Tropis. (5)2: 465-477

Rasjid A. 2004. Berbagai manfaat algae. J. Oseanologi di Indonesia, 3:9-15.

Romimohtarto, K dan Sri Juwana. 2005. Biologi Laut. Ilmu Pengetahuan Tentang Biota Laut. Penerbit Djambatan. Jakarta.

Rosdiana. 2017. Struktur Komunitas Makroalga di Perairan Waworaha Kecamatan Soropia. Universitas Halu Oleo. Kendari

Setyobudiandi. I., Soekendarsi, E., Juariah, U., Bahtiar., Hari., H. 2009. Sari Biota Laut Rumput Laut Indonesia Jenis dan Upaya Pemanfaatan. Unhalu Press. Kendari .

Smith. A.J., 2004. Medicinal and Pharmaceutical Uses of Seaweed Natural Products: A review. Jurnal of Applied Phycology. 16:245-262

Sukiman, Musplah. A, Astuti. P. S, Ahyadi. H, Aryanti. E, 2014. Keanekaragaman dan Distribusu Spesies Makroalga di Wilayah Sekotong Lombok Barat. Jurnal Penelitian Umbrah. (18)2:71-81

Widyartini. D. S, Insan. I. A . H, dan Sulistyani. 2011. Keanakaragaman Spesies Rumput Laut Coklat Phaeophyceae Pada Substrat Karang Pantai Menganti Kebumen. Prosiding Seminar Nasional Hari Lingkungan. Universistas.

Widyastuti, S., 2008. Pengolahan Pasca Panen Alga Merah Strain Lokal Lombok Menjadi Agar-agar Menggunakan Dua Metode Ekstraksi. Jurnal Penelitian Unram (2)14:63-7

Wulhan, 2006. Komposisi dan Kepadatan Makroalga Berdasarkan Kedalaman pada Keramba Jaring Apung di Perairan Desa Sorue Jaya Kecamatan Soropia Kabupaten Konawe. Universitas Halu Oleo. Kendari

Yudasmara, A. 2011. Analisis Komunitas Makroalga di Perairan Pulau
Menjangan Kawasan Taman Nasional Bali Barat. Disertasi. IPB Bogor. 